Proc. Estonian Acad. Sci. Geol., 2002, 51, 3, 135-142

\title{
New species of Estlandia (Clitambonitidina, Brachiopoda) in the Upper Ordovician of the East Baltic
}

\author{
Michael Zuykov and Linda Hints ${ }^{\mathrm{b}}$ \\ a Department of Paleontology, St. Petersburg State University, 16 Liniya 29, St. Petersburg 199178, \\ Russia; zuykov@riand.spb.su \\ b Institute of Geology, Tallinn Technical University, Estonia pst. 7, 10143 Tallinn, Estonia; \\ Linda.Hints@gi.ee
}

Received 9 July 2001, in revised form 29 November 2001

\begin{abstract}
A new species of the gonambonitid genus Estlandia, E. hispida, is described from the lower part of the Upper Ordovician in Estonia and northwestern Russia (Ingria). The new species differs clearly from the most similar species E. marginata (Pahlen) in the external sculpture, in having less convex valves, and in the stratigraphical distribution.
\end{abstract}

Key words: Brachiopoda, Rhynchonelliformea, Gonambonitidae, Upper Ordovician, Estonia, northwestern Russia.

\section{INTRODUCTION}

The gonambonitid genus Estlandia is one of the endemic brachiopods in the Ordovician of Baltoscandia (Jaanusson 1979; Cocks \& Fortey 1998). Up to now, eight species and subspecies of the genus have been recorded from the Aseri to Keila stages of Estonia and Russia (Öpik 1930, 1934; Rubel 1963; Alikhova 1953, 1969; Vinn 2001). A possible occurrence of pre-Aseri Estlandia is mentioned in Rubel (1961).

The aim of this paper is to legalize the early Upper Ordovician (lower Caradoc) species, described first by Männil as Estlandia n. sp. in his manuscript of 1947 and mentioned later by Rõõmusoks (1970, table 12). Only few specimens were known to Männil, which clearly differed from those of the most similar species E. marginata (Pahlen), the type species of the genus. New finds, including the 
ventral and dorsal interiors, enable us to present a more complete description of this, as yet unpublished species.

The specimens figured here are deposited in the Institute of Geology at Tallinn Technical University (GI TTU, under the collection number 321) and in the Central Scientific-Research Geological Exploration Museum named after F. N. Chernyshev (CNIGR, under the collection number 13071), St. Petersburg. The figured specimen of E. marginata (Pahlen) (1209/g9:24) belongs to the Estonian Natural History Museum in Tallinn (NHMT).

\section{DISTRIBUTION OF ESTLANDIA}

The distribution of the genus Estlandia is confined to the Middle and Upper Ordovician of the North Estonian Confacies Belt and the northwestern part of the Moscow Basin (Rubel 1963; Alikhova 1969). The westernmost finds of Estlandia (E. catellatus odini Vinn in the uppermost Middle Ordovician Uhaku Stage) are known from Osmussaar Island, NW Estonia (Vinn 2001), and the easternmost ones (E. marginata (Pahlen) and E. pyron silicificata Öpik) from the Pestovo drill core in the eastern part of the Novgorod region, Russia (Alikhova 1969) (Fig. 1). In the Pestovo drill core, the last two species are identified in the Upper Ordovician Kukruse and Haljala stages, respectively. Thus the distribution area of that genus extends over $700 \mathrm{~km}$ in the shallow water facies of the Baltic Basin. E. hispida, described here, occurs (Fig. 1) in the argillaceous limestones of the Gryazno Formation (lower Idavere Substage, Haljala Stage) in the western part of the St. Petersburg region (Zuykov \& Hints 2001), and of the Vasavere Formation (upper Idavere Substage) in North Estonia (Fig. 2).

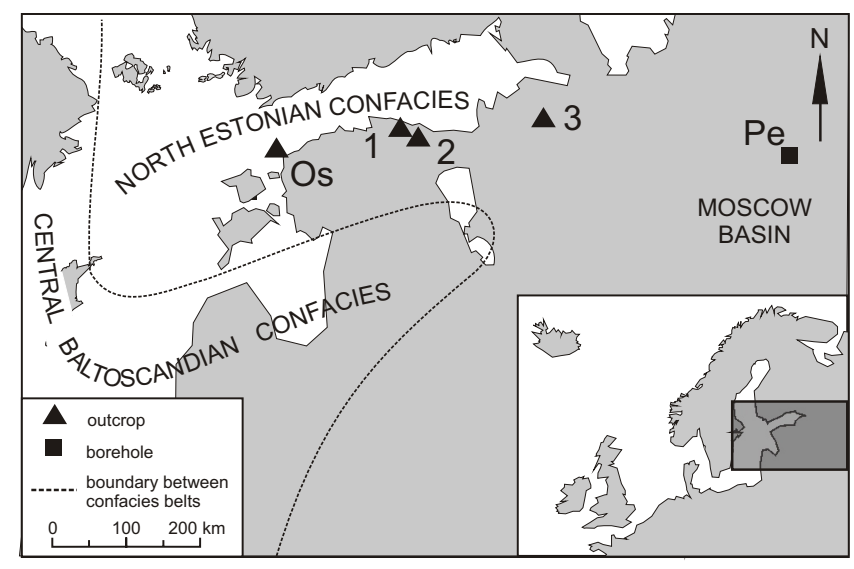

Fig. 1. Localities with Estlandia hispida: 1, Kavastu; 2, Aluvere; 3, Klyasino. Os, Osmussaar, the westernmost and Pe, Pestovo drill core, the easternmost locality with Estlandia. 


\begin{tabular}{|c|c|c|c|c|c|c|c|c|}
\hline \multirow{2}{*}{$\frac{\varepsilon}{\frac{\omega}{\omega}}$} & \multirow{2}{*}{ 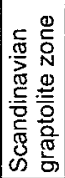 } & \multirow{2}{*}{ 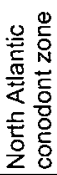 } & \multicolumn{3}{|c|}{$\begin{array}{c}\text { North Estonia } \\
\text { (Jaanusson 1995; Nőlvak 1997) }\end{array}$} & \multicolumn{3}{|c|}{$\begin{array}{l}\text { NW Russia, } \\
\text { St. Petersburg region } \\
\text { (Popov 1997) }\end{array}$} \\
\hline & & & Stage & Substage & $\begin{array}{c}\text { Forma } \\
\text { tion }\end{array}$ & Stage & Substage & $\begin{array}{c}\begin{array}{c}\text { Forma- } \\
\text { tion }\end{array} \\
\end{array}$ \\
\hline \multirow{3}{*}{ 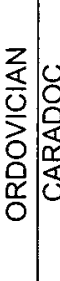 } & \multirow{3}{*}{ 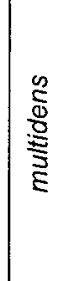 } & \multirow{3}{*}{$\begin{array}{l}\frac{9}{\omega} \\
\frac{2}{\Phi} \\
\frac{\pi}{2} \\
2\end{array}$} & \multirow{3}{*}{ Haljala } & Jõhvi & & Jõhvi & & \\
\hline & & & & \multirow{2}{*}{ Idavere } & 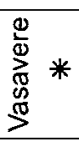 & \multirow{2}{*}{ Idavere } & $\begin{array}{l}\text { Schundo- } \\
\text { rovo }\end{array}$ & 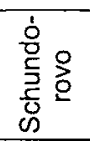 \\
\hline & & & & & 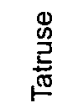 & & Ojamaa & 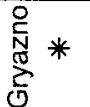 \\
\hline
\end{tabular}

Fig. 2. Correlation scheme and stratigraphical distribution of Estlandia hispida (marked by asterisk).

\section{SYSTEMATIC DESCRIPTION}

Suborder CLITAMBONITIDINA Öpik, 1934

Superfamily CLITAMBONITOIDEA Winchell \& Schuchert, 1893

Family GONAMBONITIDAE Schuchert \& Cooper, 1931

Genus Estlandia Schuchert \& Cooper, 1931

Estlandia hispida sp. nov.

Plate I, figures 1-11; Figures 3 and 4

Derivation of name: Latin hispidus, rough, referring to the specific ornamentation. The term hispida was written on a label in the box with the holotype and supposedly was used by Männil as a species name.

Holotype. Complete shell GI TTU, No. 321-1, Pl. I, figs. 4-8; northern Estonia, Aluvere quarry, Vasavere Formation, Idavere Substage of the Haljala Stage, lowermost Upper Ordovician (Caradoc).

Material and distribution. A complete shell from Aluvere quarry and a ventral valve from Kavastu old quarry, North Estonia, Vasavere Formation; a ventral valve and two dorsal valves from Klyasino quarry, St. Petersburg region, Russia, Gryazno Formation.

Diagnosis. Medium-sized Estlandia with 4-5 costae per $5 \mathrm{~mm}$ at $5 \mathrm{~mm}$ anterior to umbo, and along anterior margin, separated by interspaces two to three times width of costae; concentric filae forming chain-like crests on top of ribs; spondylium wide and relatively short; subperipheral rims absent from both valves. 
PLATE I

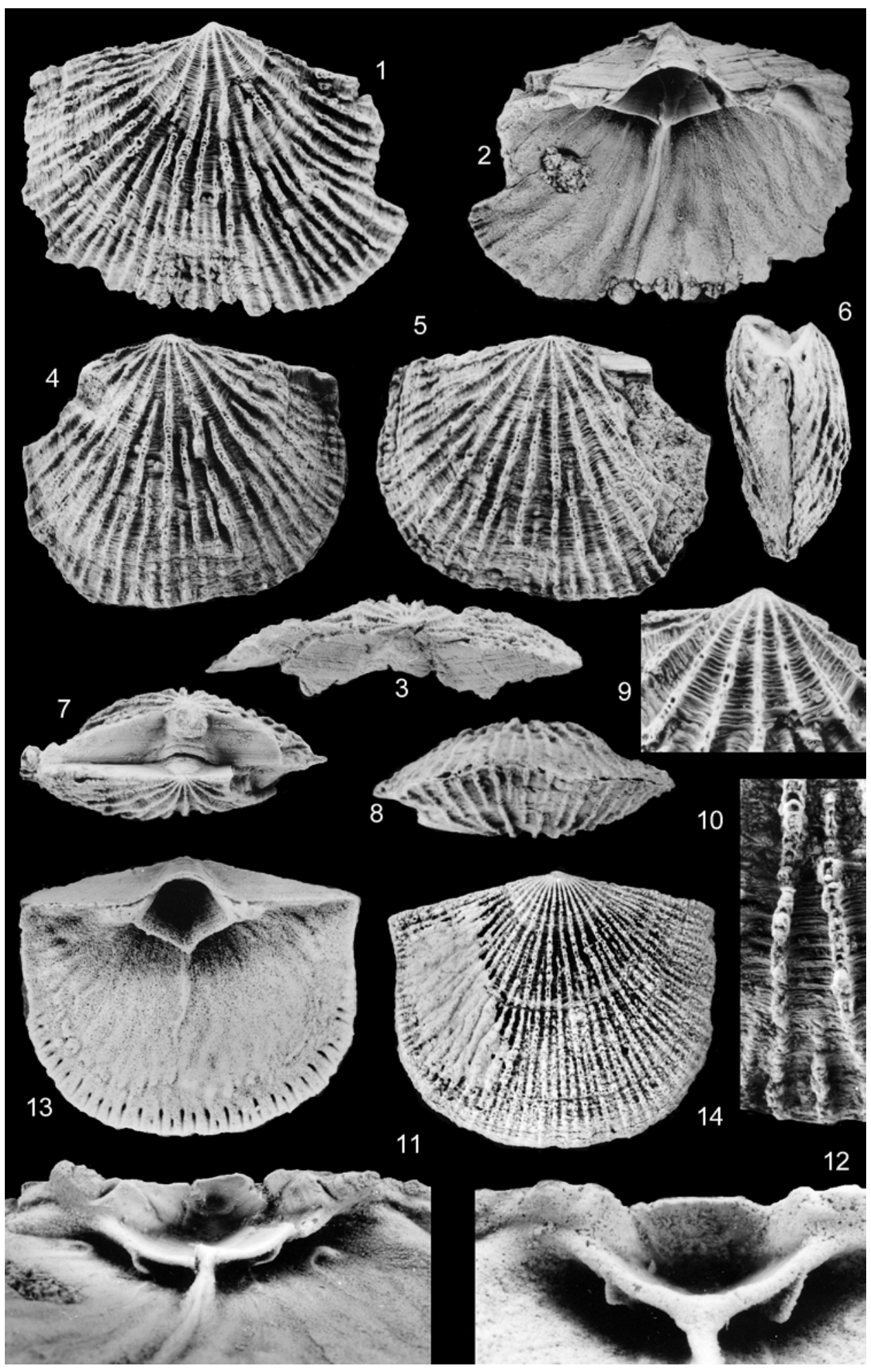


Fig. 3. Estlandia hispida. Pedicle valve No. 321-2 (GI TTU collection); view of the ventral area (A), and spondylium from the anterior side $(\mathrm{B})$; cf, crural fossette; ls, lateral septa; t, teeth. A, B $\times 2.9$.
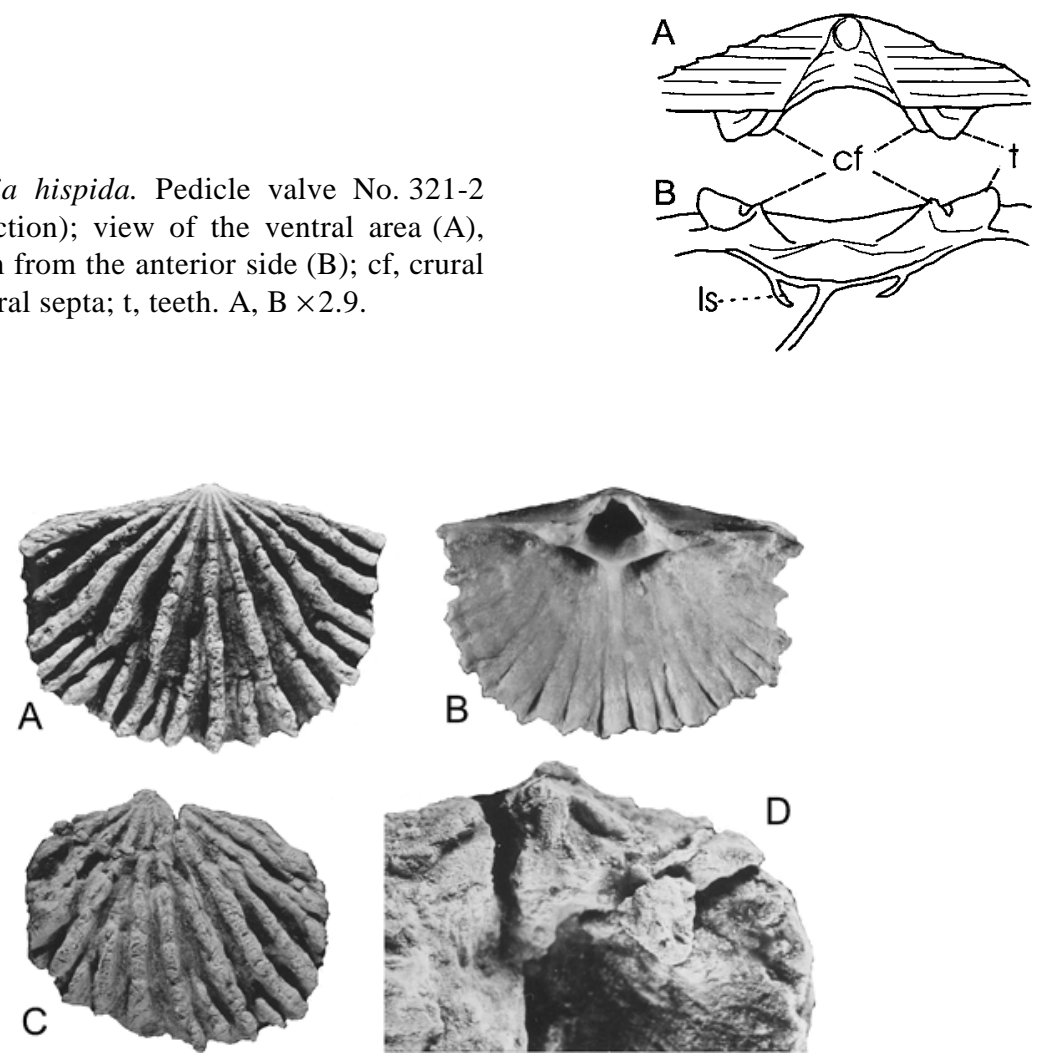

Fig. 4. Estlandia hispida. A, B, exterior and interior views of the ventral valve No. 1/13071 (CNIGR collection); C, D, exterior, and the posterior part of the interior of the dorsal valve No. 2/13071 (CNIGR collection). A-C $\times 2, \mathrm{D} \times 5$.

Description. Unequally biconvex shell with posteriorly weakly convex, anteriorly flat ventral valve and evenly convex dorsal valve. Maximum width at hinge line or at mid-valve of the shell. Outline subrectangular, cardinal extremities acute or obtuse at later growth stages (Pl. I, figs. 1, 4, 5). Anterior commissure weakly

\section{Explanation of Plate I}

Figs. 1-11. Estlandia hispida Zuykov \& Hints. 1-3, 9-11, ventral valve No. 321-2 (GI TTU) North Estonia, Kavastu: $1-3$, exterior, interior, and posterior views, $\times 2$; $9-11$, view of the posterior part of the valve with concentric filae, chain-like crests on the costellae, and anterior view of spondylium triplex, $\times 6$. 4-8, holotype, complete shell No. 321-1 (GI TTU) North Estonia, Aluvere, Haljala Stage: 4, 5, ventral and dorsal exteriors; 6-8, lateral, posterior, and anterior views. All $\times 1.5$.

Figs. 12-14. Estlandia marginata (Pahlen); No. 1209/g9:24 (NHMT), North Estonia, Kohtla, Kukruse Stage; view of the spondylium triplex, interior and exterior of the ventral valve; 13 and $14 \times 1.5,12 \times 4$. 
sulcate. Ventral interarea triangular, apsacline, flat, about one quarter as high as wide. Delthyrium in a form of isosceles triangle, covered by convex deltidium with large sealed foramen extending for about half of the deltidium height (Fig. 3B). Parallel growth lines cover the ventral interarea and deltidium. Dorsal interarea flat, anacline, about half as high as ventral interarea. Notothyrium covered by convex chilidium, about as wide as high.

Radial ornamentation costellate, with 10 and 11 primary costae respectively on the dorsal and the ventral valve (Table 1). New costellae originate by intercalation at different growth stages, with the first one appearing about $5 \mathrm{~mm}$ from the umbo. The costae and costellae form high, narrow ridges of about the same width for the most part of the valve surface, with $4-5$ ribs per $5 \mathrm{~mm}$ at $5 \mathrm{~mm}$ from the umbo and along the anterior margin (Pl. I, figs. 1, 4, 5, 9, 10). The intercostal spaces are two to three times wider than the ribs. Regular concentric filae, 5-6 per mm, cover the entire shell surface, including intercostal space. The closely spaced filae cut back anteriorly, forming chain-like crests on the ribs (Pl. I, fig. 10). Growth lines are more clearly developed only in the lateral parts of the shell (Pl. I, figs. 1, 4). The asymmetry of radial ornamentation occurs on all specimens.

Ventral interior with triangular teeth located laterally from the sides of delthyrium. From the side of spondylium the teeth are supported by the secondary shell material which forms an additional (inner) plate of the teeth, folded anteriorly and serving as "raised" crural fossette (see Wright \& Rubel 1996). Spondylium triplex about two-fifths as long as ventral valve, weakly concave, with anterior margin extending slightly anteriorly in the middle part. Median septum narrow and short. Lateral septa thin, free anteriorly, converging towards the median septum (Fig. 3C). Inner shell surface covered by shallow pits.

The simple ridge-like cardinal process of the dorsal valve fused with the chilidium (Fig. 4). Socket ridges long, widely divergent. Median septum low, blade-like, extending anteriorly for about half of the valve length.

Shell substance pseudopunctate.

Table 1. Measurements and number of ribs of Estlandia hispida

\begin{tabular}{|c|c|c|c|c|c|}
\hline \multirow[t]{2}{*}{ Specimen } & \multicolumn{2}{|c|}{ Length of valve, $\mathrm{mm}$} & \multirow{2}{*}{$\begin{array}{l}\text { Width, } \\
\mathrm{mm}\end{array}$} & \multicolumn{2}{|c|}{ Number of ribs } \\
\hline & Ventral & Dorsal & & Primary & In $5 \mathrm{~mm}$ \\
\hline $\begin{array}{l}\text { Holotype, complete shell, } \\
\text { No. } 321-1\end{array}$ & 26.1 & 25.4 & 31.5 & 11 & $4-5$ \\
\hline Ventral valve, No. 321-2 & $21.2+$ & - & 28.4 & 11 & $4-5$ \\
\hline Ventral valve, No. 1/13071 & 13.0 & - & 19.0 & $10+$ & $3-4$ \\
\hline Dorsal valve, No. 2/13071 & - & 12.0 & 14.0 & $9+$ & 4 \\
\hline
\end{tabular}


Discussion. The described species closely resembles Estlandia marginata (Öpik 1934) from the Kukruse Stage of North Estonia in general shape and size of the shell (see Pl. I, compare figs. 1, 5, and 11). E. hispida differs from E. marginata in a somewhat larger shell and less convex valves. The new species differs from all other representatives of Estlandia in its external ornament with a small number of high primary costae, relatively large interspaces between them, and the absence of the subperipheral rim.

\section{ACKNOWLEDGEMENTS}

The authors thank A. D. Wright and M. Rubel for the critical reading of the manuscript. We are grateful to S. Terentiev (VSEGEI) for granting specimens of E. hispida from the St. Petersburg region, O. Vinn (University of Tartu) for the information on the distribution of Estlandia, G. Baranov (Institute of Geology TTU) and P. V. Stepanov (VSEGEI) for making the photographs. The work of the first author was partly supported by the Paleontological Society (PalSIRP, Sepkoski grant) and The Percy Sladen Memorial Fund, and of the second author by the Estonian Science Foundation (grant No. 4674). This paper is a contribution to IGCP Project 410.

\section{REFERENCES}

Alikhova, T. N. 1953. Rukovodyashchaya fauna brakhiopod ordovikskikh otlozhenij severozapadnoj chasti Russkoj platformy. Gosgeoizdat, Moscow (in Russian).

Alikhova, T. N. 1969. Stratigrafiya i brakhiopody sredneordovikskikh otlozhenij Moskovskoj sineklizy. Nedra, Moscow (in Russian).

Cocks, L. R. M. \& Fortey, R. A. 1998. The Lower Palaeozoic margins of Baltica. GFF, 120, 173179.

Jaanusson, V. 1979. Ordovician. In Treatise on Invertebrate Paleontology, Vol. A (Moore, R. C., ed.), pp. A136-A166. Geol. Soc. Amer. and Univ. Kansas Press.

Jaanusson, V. 1995. Confacies differentiation and upper Middle Ordovician correlation in the Baltoscandian Basin. Proc. Estonian Acad. Sci. Geol., 44, 73-86.

Nõlvak, J. 1997. Ordovician. Introduction. In Geology and Mineral Resources of Estonia (Raukas, A. \& Teedumäe, A., eds.), pp. 52, 54, 55. Estonian Acad. Publ., Tallinn.

Männil, R. 1947. Idavere lademe stratigraafiast ja faunast Eesti NSV-s. Manuscript deposited in the Central Archives in Tallinn (fund R-2346, list 3, object 218) (in Estonian).

Öpik, A. 1930. Brachiopoda Protremata der estländischen ordovizischen Kukruse-Stufe. Acta Comment. Univ. Tartuensis A XVII, I; Publ. Geol. Inst. Univ. Tartu No. 20.

Öpik, A. 1934. Über Klitamboniten. Tartu Ülik. Geol. Inst. Toim., 39.

Popov, L. E. (ed.). 1997. WOGOGOB Excursion Guide St. Petersburg, Russia 1997. Uppsala Univ.

Rubel, M. P. 1961. Lower Ordovician brachiopods of the superfamilies Orthacea, Dalmanellacea and Syntrophiacea of Eastern Baltic. ENSV TA Geol. Inst. Uurimused, 6, 141-226 (in Russian).

Rubel, M. P. 1963. On Baltic Lower Ordovician Gonambonitids (Clitambonitacea, Brach.). ENSV TA Geol. Inst. Uurimused, 13, 83-108 (in Russian). 
Rõõmusoks, A. 1970. Stratigraphy of the Viruan Series (Middle Ordovician) in Northern Estonia. Valgus, Tallinn (in Russian).

Vinn, O. 2001. A new subspecies of the clitambonitidine brachiopod Estlandia catellatus from the middle Ordovician of Osmussaar Island, Estonia. Proc. Estonian Acad. Sci. Geol., 50, 86-94.

Wright, A. D. \& Rubel, M. 1996. A revision of the morphological features affecting the classification of the clitambonitidine brachiopods. Palaeontology, 39, 53-75.

Zuykov, M. A. \& Hints, O. 2001. The Gryazno Formation (Early Caradoc) in the western part of the St. Petersburg Region. In WOGOGOB-2001 Working Group on the Ordovician Geology of Baltoscandia Øresund Region, mid-May 2001. Abstracts (Harper, D. A. T. \& Stouge, S., eds.), pp. 31-32. Copenhagen.

\title{
Estlandia (Clitambonitidina, Brachiopoda) uus liik Ida-Baltikumi Ülem-Ordoviitsiumist
}

\author{
Mihhail Zuikov ja Linda Hints
}

On kirjeldatud perekonna Estlandia uus liik Põhja-Eesti ja Leningradi oblasti Ülem-Ordoviitsiumi alumisest osast, vastavalt Vasavere ja Grjazno kihistust. Liiki on esialgselt lühidalt kirjeldanud R. Männil oma käsikirjalises töös (1947), kus on esile toodud uue liigi erinevus perekonna tüüpliigist E. marginata (Pahlen).

\section{Новый вид Estlandia (Clitambonitidina, Brachiopoda) из верхнего ордовика Восточной Балтики}

\author{
Михаил Зуйков и Линда Хинтс
}

На основе отобранных образцов брахиопод из отложений верхнего ордовика (нижнего карадока) Северной Эстонии и Ленинградской области описан новый вид рода Estlandia. Первые краткие сведения об этом виде приведены в рукописи Р. Мянниля (1947). 